\title{
ILO CONTRIBUTIONS TO THE JURISPRUDENCE OF INTERNATIONAL HUMAN RIGHTS BODIES
}

The paper addresses the role of the International Labour Organization (ILO) in the consideration of cases and in the interpretation of international human rights instruments by the Committee on Economic, Social and Cultural Rights and the European Court of Human Rights. As labour rights form part of internationally recognized human rights the author attempts to evaluate the penetration of ILO standards and legal reasoning into the adjudication of human rights cases and interpretation of human rights instruments by other international bodies. The analysis of the jurisprudence of the CESCR and the ECtHR demonstrates that the ILO standards and the legal reasoning are always referred to in the cases related to labour rights and serve as a source of "substantial filling" of both the International Covenant on Economic, Social and Cultural Rights and the European Convention on Human Rights.

Keywords: labour rights, human rights, ECtHR, ILO, CESCR

"There are few organizations that have succeeded to the extent that the ILO has, in translating into action the fundamental moral idea on which it is based."

Mrs Aase Lionaes, Chair of the Nobel Committee

Elena Sychenko, Ph.D., Associate Professor, Faculty of Law, Saint Petersburg State University, ul. K. Marksa, d. 36a, kv. 21, Gatchina, Leningrad region, Russia; e.sychenko@mail.ru;

ORCID ID: orcid.org/0000-0002-7045-9218 


\section{INTRODUCTION}

Jubilee is traditionally the great moment to celebrate success and evaluate what has been done. The ILO centenary is a reason to recall how much has been done to ensure the protection of a worker and to get prepared for the new challenges. The ILO Global centenary report ${ }^{1}$ and the Centenary Declaration ${ }^{2}$ are the results of such reflection, they called for a human-centered agenda for the future of work and the universal labour guarantees. These are the new notions for the international labour law, though their content is not new at all. Their roots might be found in the words that have become the motto of the ILO: "Labour is not a commodity".

The remarkable steps taken by the ILO since its establishment in 1919 were aimed at placing human dignity at the centre of economic development. ${ }^{3}$ Starting from the regulation of labour issues in certain industries ILO elaborated the list of fundamental principles and rights at work ${ }^{4}$ in 1998 which are binding for any country member whether the relevant convention is ratified. ${ }^{5}$ The eight fundamental ILO Conventions are ratified by more than two-thirds of all member states ${ }^{6}$ and the most recent Worst Forms of Child Labour Convention, 1999 (No. 182) has reached universal ratification in 2020. Throughout these 100 years, the most vulnerable groups of workers have become the subjects of

1 Work for a brighter future, Global Commission on the Future of Work, International Labour Office, ILO, Geneva, 2019, https://www.ilo.org/wcmsp5/groups/public/--dgreports/---cabinet/documents/publication/wcms_662410.pdf.

2 ILO Centenary Declaration for the Future of Work, 2019, https://www.ilo.org/wcmsp5/ groups/public/@ed_norm/@relconf/documents/meetingdocument/wcms_711674. pdf.

3 See, for example, Dupré, C., The Age of Dignity: Human Rights and Constitutionalism in Europe, Bloomsbury Publishing, London, 2016, p. 50.

4 These are the freedom of association and the effective recognition of the right to collective bargaining; the elimination of all forms of forced or compulsory labour; the effective abolition of child labour; and the elimination of discrimination in respect of employment and occupation.

5 See, for example, Kellerson, H., The ILO Declaration of 1998 on fundamental principles and rights: A challenge for the future, International Labour Review, no. 137, 1998, p. 223.

6 See https://www.ilo.org/dyn/normlex/en/f?p=1000:12001:::NO::: 
special protection (domestic workers ${ }^{7}$, migrants $^{8}$, disabled people ${ }^{9}$ ) and the call for ensuring social security has become stronger. ${ }^{10}$ It is a brief list of the ILO contributions to social justice all over the world. To be fair, it should be noticed that ILO activities have been often criticized for their ineffectiveness ${ }^{11}$, inadequacy of its politics to the current situation in the field of work, its recruitment and its decision-making policies. ${ }^{12}$ References to the ILO mechanism as to the "toothless tiger"13 or a "name and shame"14 mechanism might also be found in different publications. However, in the present paper, the main idea is to focus on the "bright side" of the activities of the ILO to underline its contributions to the jurisprudence of international human rights bodies.

The first part will deal with a more general point: the links between human rights at work and the ILO, the second - consider the practical implementation of the ILO standards in the jurisprudence of the Committee on Economic, Social and Cultural rights (CESCR). The third one will provide reflections about the role of the ILO in the legal reasoning of the European Court of Human Rights (ECtHR).

See Domestic Workers Convention, 2011 (No. 189); Albin, E.; Mantouvalou V., The ILO convention on domestic workers: From the shadows to the light, Industrial law journal, vol. 41, no. 1, 2012, pp. 67-78.

8 See Maintenance of Migrants' Pension Rights Convention, 1935 (No. 48); Migrant Workers (Supplementary Provisions) Convention, 1975 (No. 143).

9 See Vocational Rehabilitation and Employment (Disabled Persons) Convention, 1983 (No. 159).

10 See Social Security (Minimum Standards) Convention, 1952 (No. 102).

11 Klabbers, J., Marginalised International Organizations: Three Hypotheses Concerning the ILO, in Blanpain, R.; Liukkunen U.; Yifeng C. (eds.), China and ILO Fundamental Principles and Rights at Work, Kluwer, 2014, p. 185.

12 Standing, G., The ILO: An agency for globalization?, Development and Change, vol. 39, 2008, pp. 355-384.

13 Lyutov, N., The ILO System of International Labour Standards and Monitoring Procedures: Too Complicated to Be Effective, Zbornik Pravnog Fakulteta u Zagrebu, vol. 64, no. 2, 2014, pp. 255-276; Carpenter, K., The International Covenant on Civil and Political Rights: A Toothless Tiger, North Carolina Journal of International Law, vol. 26, 2000 , p. 1.

14 Koliev, F.; Lebovic, J., Selecting for Shame: The Monitoring of Workers' Rights by the International Labour Organization, 1989 to 2011, International Studies Quarterly, vol. 62, no. 2, 2018, pp. 437-452. 


\section{ILO AND HUMAN RIGHTS}

\subsection{Interconnection between the ILO and Human Rights}

The ILO was a pioneer in acknowledging economic and social human rights. ${ }^{15}$ Before the adoption of the International Human Rights Covenants in 1966, ILO Conventions were the only universal human rights instruments acknowledging the obligations of the states to provide the freedom of association, ensure the prohibition of discrimination and forced labour. The majority of ILO fundamental conventions were adopted before $1965^{16}$, the year of adoption of the first UN Human Rights instrument - International Convention on the Elimination of All Forms of Racial Discrimination. It was noted by scholars in 1966, that the ILO was "not only effectively protecting human rights, as they are interrelated with the protection of trade union freedom, but it was setting the precedent and leading the way for other specialized groups". ${ }^{17}$ The labour rights enshrined later in the Covenants were "originally outlined in the ILO Constitution" and "served as the source of the Universal Declaration and the European Social Charter". ${ }^{18}$

It is important to underline the lack of traditional separation of human rights into political and social in the activities of the ILO. The former ILO president, Professor Jenks argued that there should be no separation of human freedoms and economic rights and that ILO stands on it. ${ }^{19}$ This approach was later expressed in the Teheran Proclamation on Human Rights, which stated that "since human rights and fundamental freedoms are indivisible, the full realization of civil and political rights without the enjoyment of economic and

15 Cassin, R., L'homme, sujet de droit international, et la protection des droits de l'homme dans la societe universelle, in Rousseau, C. (ed.), La technique et les principes du droit public. Etude en l'honneur de Georges Scelle, vol. 1, Librairie générale de droit et de jurisprudence, vol. 1, 1950, p.68.

16 Freedom of Association and Protection of the Right to Organise Convention, 1948 (No. 87); Right to Organise and Collective Bargaining Convention, 1949 (No. 98); Forced Labour Convention, 1930 (No. 29); Abolition of Forced Labour Convention, 1957 (No. 105); Equal Remuneration Convention, 1951 (No. 100); Discrimination (Employment and Occupation) Convention, 1958 (No. 111).

17 Gormley, P., The Emerging Protection of Human Rights by the International Labour Organization, Albany Law Review, vol. 30, 1966, p. 14.

18 Ibid., p. 20.

19 Jenks, C. W., Human rights and international labour standards, Stevens, 1960. 
social rights is impossible". ${ }^{20} 30$ years later, the same was reaffirmed in the famous Vienna Declaration. ${ }^{21}$ Indivisibility of human rights penetrated the jurisprudence of the European Court of Human Rights (ECtHR) which in the famous case Airey v. Ireland concluded that there was no "water-tight division" separating economic and social rights from civil and political rights covered by the European Convention. ${ }^{22}$

At the time of the establishment of the human rights bodies both on the universal and regional level (Council of Europe), ILO already developed norms on individual and collective rights at work and elaborated the interpretation of these norms in the jurisprudence of its bodies. Here we need to mention the Committee of Experts on the Application of Conventions and Recommendations (CEACR) and the Committee on Freedom of Association (CFA). The former was set up in 1926 to examine the government reports on ratified Conventions. The latter was founded in 1951 to examine the complaints of violations of freedom of association, whether or not the country concerned had ratified the relevant ILO Conventions. These committees have elaborated the meaning of the norms set in the ILO Conventions adopting a detailed interpretation that often went far beyond the literal text of the Convention.

These interpretations are often referred to as the "soft law". ${ }^{23}$ Despite the "soft" and therefore non-binding nature of these interpretations, they are "widely respected, at both domestic and international level, and regularly inform the meaning of labour laws in domestic and international courts and other international institutions". ${ }^{24}$ Scholars affirmed that ILO standards serve as a source of legitimacy and interpretative guidance for regional human rights courts ${ }^{25}$, that

20 International Conference on Human Rights, Proclamation of Teheran, Final Act of the International Conference on Human Rights, 22 April to 13 May 1968, A/CONF. 32/41 at 3, para. 13, cited from De Beco, G., The Indivisibility of Human Rights and the Convention on the Rights of Persons with Disabilities, International \& Comparative Law Quarterly, vol. 68, no. 1, 2019, p. 144.

21 Vienna Declaration and Programme of Action adopted by the World Conference on Human Rights in Vienna on 25 June 1993, https://www.ohchr.org/en/professionalinterest/pages/vienna.aspx.

ECtHR, Airey v. Ireland (6289/73) 09/10/1979, para. 26.

23 Brudney, J., The internationalization of sources of labour law, University of Pennsylvania Journal of International Law, vol. 39, 2017, pp. 1-71.

24 Monaghan, K., The Committee of Experts on the Application of Conventions and Recommendations: The Centenary Year, King's Law Journal, vol. 32, no. 2, 2021, p. 202.

25 Ebert, F.; Oelz, V., Bridging the gap between labour rights and human rights: The role of ILO law in regional human rights courts, ILO, 2012. 
they help to contextualise human rights questions in the employment sphere. ${ }^{26}$ International human rights bodies both globally and on regional level use it as the main source of legal reasoning once the issue concerns labour rights or other matters covered by the ILO; the examples will be provided in the further parts of the paper.

\subsection{The legal basis and the reasons for referring to the ILO standards}

The reference to the ILO Conventions in international human rights jurisprudence is based on Article 31 of the Vienna Convention on the Law of Treaties (VCoLT), which provided the opportunity to refer to "any relevant rules of international law applicable in the relations between the parties" for the interpretation of international treaties. "Applicable in the relations" evidently means that only those norms are taken into account which are ratified by the relevant states. The reference to the "rules" means that the norms are used as a source of interpretation but not the binding interpretation of these norms by an international body.

Interestingly, speaking about the use of the ILO standards in the jurisprudence of the human rights bodies, we can trace both the references to standards which were not ratified by the respondent state and to the legal positions of the ILO bodies which do not create norms, but rather recommendations (CEACR, CFA). Thus, in the case against Kenya ${ }^{27}$ the African Commission on Human and Peoples' Rights referred to the Indigenous and Tribal Peoples Convention, 1989 (No. 169) on the rights of indigenous peoples and noted that "even though many African countries have not signed and ratified the said Convention there is a common thread that runs through all the various criteria that attempt to describe indigenous peoples - that indigenous peoples have an unambiguous relationship to a distinct territory and that all attempts to define the concept recognize the linkages between people, their land, and culture". The Commission further stated that the Government must consult indigenous peoples especially when dealing with sensitive issues as land (which is one of the key norms of

26 Mantouvalou, V., Labour Rights in the European Convention on Human Rights: An Intellectual Justification for an Integrated Approach to Interpretation, Human Rights Law Review, vol. 13, no. 3, 2013, pp. 529-555.

27 Centre for Minority Rights Development (Kenya) and Minority Rights Group International on behalf of Endorois Welfare Council v. Kenya, 276/2003, African Commission on Human and Peoples' Rights, 4 February 2010, available at: https:// www.refworld.org/cases,ACHPR,4b8275al2.html [accessed 26 November 2021]. 
the Convention No. 169) and found the violation of the African Charter on Human and Peoples' Rights.

The Inter-American Commission on Human Rights (IACHR), considering the case on the rights of indigenous people, determined that the provisions of the American Declaration on the Rights and Duties of Man should be "interpreted and applied in the context of the indigenous petitioners with due regard to the particular principles of international human rights law governing the individual and collective interests of indigenous peoples". ${ }^{28}$ It further considered that the Indigenous and Tribal Peoples Convention, 1989 (No. 169), although it was ratified by only 22 countries by that time, "is the international human rights instrument most relevant to the protection of indigenous rights and that its provisions are fundamental in interpreting the inter-American human rights standards in petitions filed against the Member States". ${ }^{29}$

These positions of the regional human rights bodies underline the value of the ILO standards and seem to treat them as jus cogens norms. ${ }^{30}$ Illustrating the value of the positions of the ILO bodies we might refer to the recent cases considered by the Inter-American Commission and the Inter-American Court. The former considered in 2019 the case "Former Employees of the Judiciary v. Guatemala" on dismissal of sixty-five employees of the judiciary who took part in a strike. In this case, the Commission, to substantiate its finding on the need to guarantee the right to strike under Article 26 of the American Convention on Human Rights (though this right is not fixed in the text), cited the ILO Committee on Freedom of Association and the Committee of Experts. The cited ILO legal positions emphasized the essential and basic character of the right to strike and listed the cases when this right might be restricted or prohibited. ${ }^{31}$

The Inter-American Court of Human Rights issued in 2021 its remarkable advisory opinion concerning the freedom of association under the request of

28 IACHR. Case of Mary and Carrie Dann v. the United States of America. Merit Report 75/02 dated December 27, 2002, para. 131.

29 Madariaga Cuneo, I., ILO Convention 169 in the inter-American human rights system: consultation and consent, The International Journal of Human Rights, vol. 24, no. 2-3, 2020, pp. 257-264.

30 See the reflections about the jus cogens norms in international labour law in Lyutov, N., Norms of jus cogens and international labor law, Lex Russica, no. 12, 2014, pp. 1547-1556.

31 IACHR, Case of Former Employees of the Judiciary v. Guatemala, Case 12.432, Report no. 157/19, 28 September 2019, paras. 58-60. See also Chacón, C., A Worker's Victory: Right to Strike Protected by Article 26 of the American Convention, International Labor Rights Case Law, vol. 6, no. 3, 2020, pp. 235-240. 
the Inter-American Commission on Human Rights. The Commission submitted a request for an advisory opinion on "the scope of States' obligations under the Inter-American system regarding guarantees of freedom of association, its relationship with other rights and its application from a gender perspective". 32 The information on restrictions on the exercise of freedom of association and the right to strike "in the Americas, with a focus on Brazil, Colombia, Chile, Honduras, Argentina and Costa Rica" was mentioned by the Commission as one of the reasons for submitting the request. The Inter-American Court adopted an 80-page advisory opinion, where the ILO standards and their interpretation by the CEACR and the CFA have the key role. It stated, in particular:

"In the context of the present advisory opinion, the Court considers it pertinent to emphasize that, although it is not its task to issue a direct interpretation of the various international labour law instruments, the principles, rights and obligations contained therein undoubtedly contribute decisively to determining the scope of the American Convention. Thus, by virtue of the matter submitted for consultation, the Court will take into special consideration, as additional sources of international law, the conventions and recommendations, and other relevant instruments, as well as opinions and recommendations of the Committee on Freedom of Association and the ILO Committee of Experts on the Application of Conventions and Recommendations, both of the ILO, in order to make a harmonious interpretation of the international obligations in the terms of the aforementioned conventions" (para. 53).

Applying this interpretative approach, The Inter-American Court stated, in particular, the fundamental role of the right to strike, the prohibition to derogate from legislation through collective agreements, and the interdependence, indivisibility of the freedom of association, collective bargaining and the right to strike. It noted that "respecting and guaranteeing these rights is fundamental to the protection of labour rights and fair, just and favourable conditions at work". ${ }^{33}$

Here comes the question: why do international and regional bodies refer to the ILO standards (ILO Conventions) and ILO soft-law (recommendations and conclusions of the ILO bodies)?

The first answer to this question was more or less outlined above - the long history of the organization and their role in forming the international labour standards, in other words - the authority of the ILO and its reputation as a key expert in the field of labour rights. Another reason might be in the almost

32 Inter-American Court of Human Rights. Advisory opinion oc-27/21 of 5 May 2021 https://www.corteidh.or.cr/docs/opiniones/seriea_27_esp.pdf.

33 Inter-American Court of Human Rights. Advisory opinion oc-27/21 of 5 May 2021. 
universal level of the support of the ILO: the number of country members is almost equal to the number of UN members. All of them have acknowledged the values outlined in the ILO Constitution. Special mention should be made about the tripartite character of the ILO: the international labour standards are adopted by the International labour conference, uniting workers, employers and the governments. ${ }^{34}$ The CFA is also organized on a tripartite basis. Tripartism ensures a greater legitimacy of the standards and their support by social partners. ${ }^{35}$ This point is also important for establishing the content of the human rights at work by the relevant human rights bodies as we see further in the part dedicated to the ECtHR.

Thus, even in the absence of the legal basis for the reference to the legal positions of the ILO bodies, these positions contribute to the formation of a "harmonious" interpretation of the fundamental human rights in the field of work. ${ }^{36}$

\section{ILO AND INTERNATIONAL COMMITTEE ON ECONOMIC, SOCIAL AND CULTURAL RIGHTS}

\subsection{The scope of the states' obligations}

Traditionally, one speaks about human rights in the framework of "protect-respect-fulfil" obligations of the states. ${ }^{37}$ These obligations, in the opinion of some scholars, are expressed in the general provisions of the various treaties and it has been made evident by the General Comments and jurisprudence of

34 See about the voting process at the ILO: Kaufmann, J., Conference Diplomacy: An Introductory Analysis, Third Revised Edition, Palgrave Macmillan, 2016, p. 26.

35 See, for example, Curtis, K., 100 years of the ILO in action: Reflections on inclusive collective representation and the organization's quest for social justice, King's Law Journal, vol. 32, no. 2, 2021, p. 184.

36 See on this point: Fenwick, C., The International Labour Organisation: An Integrated Approach to Economic and Social Rights, in Langford, M. (ed.), Social Rights Jurisprudence: Emerging Trends in International and Comparative Law, Cambridge University Press, 2008, pp. 591-612; Valticos, N., International Labour Standards and Human Rights: Approaching the Year 2000, International Labour Review, vol. 137, no. 2, 1998, pp. 135-147; Jenks, C., Human Rights, Social Justice and Peace: The Broader Significance of the ILO Experience, in Eide, A.; Schou, A. (eds.), International Protection of Human Rights: Proceedings of the Seventh Nobel Symposium, Oslo, September 25-27, 1967, Almqvist and Wiksell, 1968, pp. 227-60.

37 Kunnemann, R., A coherent approach to human rights, Human Rights Quarterly, vol. 17, 1995, p. 323. 
the human rights bodies implementing the treaties. ${ }^{38}$ As far as economic and social rights are concerned the duty to fulfil them becomes of a particular value as it is the positive obligation of the state to guarantee these rights. ${ }^{39}$

According to Article 2 of the ICESCR, each State Party undertakes to take steps, individually and through international assistance and cooperation, especially economic and technical, to the maximum of its available resources, to achieve progressively the full realization of the rights recognized in the present Covenant by all appropriate means, including particularly the adoption of legislative measures. The Committee on Economic, Social and Cultural Rights (CESCR), created for the supervision of the Covenant's implementation, has stated that the means used by States should be mostly legislative, but include also, between others, administrative, financial, educational and social measures. ${ }^{40}$ The words "progressively" and "to the maximum of its available resources" were the object of heavy criticism as lacking clarity and permitting the less developed states to interpret this provision broadly for the justification of the lack of action in the field of social rights. ${ }^{41}$ However, such a flexible formulation might have been the only way to ensure the adoption of the Covenant overcoming the long-lasting opposition of Soviet and capitalist blocks of countries. We need to recall that the Universal Declaration was adopted in 1948 and since then the drafting process of the binding international human rights instrument started. It took the international community almost 20 years to agree on the list of rights guaranteed and the relevant states' obligations. Therefore, the adoption of the vague definition of the State's positive obligations was much better than the absence of a binding instrument.

The lack of clarity was partly compensated by the CESCR: it has stated that "progressive realization" should not be misinterpreted as depriving the obligation

38 Skogly, S., Beyond national borders: States' human rights obligations in international cooperation, Intersentia nv, 2006, p. 60.

39 See, for example, Eide, A., Realization of Social and Economic Rights and the Minimum Threshold Approach, Human Rights Law Journal, vol. 10, no. 1-2, 1989, pp. 35-51; Sepúlveda, M., The nature of the obligations under the International Covenant on Economic, Social and Cultural Rights, Intersentia nv, 2003, pp. 123-125.

40 ICESCR, General Comments no. 3 On the Nature of State Parties' Obligations, 1990, pp. 6-7.

${ }^{41}$ Skogly, S., The Requirement of Using the 'Maximum of Available Resources' for Human Rights Realisation: A Question of Quality as Well as Quantity?, Human Rights Law Review, vol. 12, no. 3, 2012, pp. 393-420; Robertson, R., Measuring State Compliance with the Obligation to Devote the 'Maximum Available Resources' to Realizing Economic, Social, and Cultural Rights, Human Rights Quarterly, vol. 16, no. 4, 1994, pp. 693-714. 
of all meaningful content ${ }^{42}$, on the contrary, it should mean "a minimum core obligation to ensure the satisfaction of, at the very least, minimum essential levels of each of the rights is incumbent upon every State party". ${ }^{43}$

This "minimum core" of labour rights is defined by the CESCR through extensive references to the ILO conventions.

\subsection{Reference to the ILO standards in the General comments of the CESCR}

All the general comments issued to interpret articles providing labour rights include many references to the ILO standards. The General Comment No. 18: The Right to Work (Article 6 of the Covenant) refers to ten ILO Conventions covering forced and child labour, employment policy, dismissal protection, discrimination, employment of disabled people, protection against unemployment and labour statistics. ${ }^{44}$ The CESCR stated there that incorporation of international instruments setting forth the right to work into the domestic legal order, in particular the relevant ILO conventions, should strengthen the effectiveness of measures taken to guarantee the right to work and is encouraged (para. 49). It also encouraged the member states to avail themselves of the technical assistance and cooperation offered by the ILO when formulating and implementing their national employment strategies and use the extensive information and advisory services provided by the ILO for data collection and disaggregation as well as the development of indicators and benchmarks (para. 53).

In the most recent General Comment No. 23 (2016) on the right to just and favourable conditions of work, the CESCR identified twenty conventions as relevant for determining the compliance of the states with the obligations set in Article 7. Those twenty conventions cover the issues of maternity protection, working time and rest regulation, minimum wage, equal remuneration, discrimination, minimum age, occupational safety, workers with family responsibilities, night and part-time work. The CESCR underlined that the states should consider ratifying core human rights treaties and relevant ILO conventions (para. 72).

The requirements to the positive obligations of the states under Article 7 were also outlined in the General comment No. 23 (2016). The text search finds 37

42 ICESCR, General Comments no. 3 On the Nature of State Parties' Obligations, 1990, p. 9.

43 ICESCR, General Comments no. 3 On the Nature of State Parties' Obligations, 1990, p. 10.

44 ILO Conventions No. 2, 29, 88, 105, 111, 122, 158, 159, 160, 168. 
mentions of the ILO. Mostly these are the references to the ILO Conventions made to support the interpretation of labour rights by the Committee and provide additional justification to the imposition of high standards of protection. For example, the term "remuneration" in the interpretation of the ICESCR is supported by Article I (a) of the ILO Equal Remuneration Convention, 1951 (No. 100); the term remuneration includes the ordinary, basic or minimum wage or salary and any additional emoluments whatsoever payable directly or indirectly, whether in cash or kind, by the employer to the worker and arising out of the worker's employment; the coverage of the OSH policies under Article 7 of the ICESCR should include non-standard workers, apprentices and interns as it is stipulated in the ILO Occupational Safety and Health Convention, 1981 (No. 155), Article 4 (1). ${ }^{45}$

\subsection{Reference to the ILO standards in the concluding observations of the CESCR}

The research of the ICESCR jurisprudence demonstrates that ILO standards, as well as the comments by ILO bodies, are an important tool for the estimation of state's compliance with the human rights obligations under the Covenant. For example, reviewing the Colombian report the CESCR underlined the fact that the exercise of the rights to form and join trade unions, bargain collectively and strike are limited by excessive legal requirements. It was also concerned with the persistence of numerous acts of violence targeting members of trade unions. The CEACR recommended the state to bring its legislation into line with Article 8 of the Covenant and the ILO fundamental conventions No. 87, No. 98 and take effective measures to protect members of trade unions. This conclusion is in line with the ILO conclusions on the situation with trade unions' rights in Colombia, expressed in the observation by the CEACR and in several conclusions of the Committee on Freedom of Association. ${ }^{46}$ Considering the last report of Estonia in 2019 the CESCR noted that the Civil Service Act should be amended to allow civil servants who do not provide essential services to exercise their right to strike under Article 8 of the Covenant and with the International Labour Organization Freedom of Association and Protection of

45 ICESCR, General Comment No. 23 (2016) on the right to just and favourable conditions of work

46 Observation (CEACR) - adopted 2016, published 106th ILC session (2017) Freedom of Association and Protection of the Right to Organise Convention, 1948 (No. 87) - Colombia (Ratification: 1976), 10 cases were considered in respect of Colombia by CAS in 2016-2017. 
the Right to Organise Convention, 1948 (No. 87). ${ }^{47}$ Vietnam was recommended by ICESCR to remove excessive restrictions on the right to strike and to ratify ILO Conventions No. 87 and No. $98 .{ }^{48}$

These conclusions of the CESCR demonstrate that even though until now there are no general comments on Article 8 of the ICESCR, the collective labour rights are understood in consonance with the relevant ILO standards. It should be mentioned that the content of the right to social security in the Committee's practice is also largely determined by ILO standards. The different forms of social security set out in ILO Convention No. 102 are repeated, for example, in the reporting guidelines of the CESCR. ${ }^{49}$ For example, Slovenia was urged to revise the eligibility conditions and rates for social security benefits, taking into account the actual cost of living and ratify ILO Convention No. $118 .^{50}$ The CESCR also often referred to ILO Indigenous and Tribal Peoples Convention, 1989 (No. 169) requiring the states to combat discrimination against indigenous peoples and their exclusion..$^{51}$

These examples demonstrate that the ILO standards fill the gaps in the ICESCR providing concepts, standards for the regulation of the different aspects of the working conditions and also serve as a vector of development for the less developed countries who want to comply with the Covenant. Professor Valticos noted that the international labour Conventions provide, in a more specific and detailed manner, for the practical implementation, at the national level, of the series of principles embodied in more general terms in the UN Covenant on Economic, Social and Cultural Rights. ${ }^{52}$ Therefore, the ILO standards are used as a reference point for determining the human rights obligations of the states in the field of labour. At the same time, the interpretation of the CESCR serves for the promotion of the ILO standards and activities.

47 CESCR, Concluding observations on the third periodic report of Estonia E/C.12/ EST/CO/3, 27 March 2019.

48 CESCR, Concluding observations on the second to fourth periodic reports of Viet Nam, E/C.12/VNM/CO/2-4, 15 December 2014.

49 Langford, M.; King, J., Committee on Economic, Social and Cultural Rights. Past, Present and Future, in Langford, M. (ed.), Social Rights Jurisprudence: Emerging Trends in International and Comparative Law, Cambridge University Press, 2008, p. 505.

50 CESCR, Concluding observations on the second periodic report of Slovenia, 15 December 2014, N E/C.12/SVN/CO/2.

51 CESCR, Concluding observations on the fourth periodic report of Cameroon 25 March 2019, E/C.12/CMR/CO/4; Concluding observations on the second to fourth periodic reports of Viet Nam, E/C.12/VNM/CO/2-4, 15 December 2014.

52 Valticos, op. cit. (fn. 36), p. 140. 


\section{THE ILO AND THE ECtHR}

In recent years the European Court of Human Rights ("ECtHR" or "the Court") has acquired a strong position among other international bodies having authority to consider the cases on labour rights protection. The Court is no more associated with the efficient protection of solely civil and political rights because its jurisprudence now includes numerous cases on unfair dismissal ${ }^{53}$, on the protection of employee's privacy ${ }^{54}$ or occupational health. ${ }^{55}$ Judge Sorensen in 1975 proclaimed the ECHR to be a "living legal instrument" and emphasised the need to take into account current circumstances of life by using an evolutive interpretation method. ${ }^{56}$

\section{1. "Open paradigm" in labour-related cases}

The references to the international labour standards permit the Court to develop the interpretation of the Convention to ensure the protection of certain labour rights. The examples of the integration of new rights are numerous: the right for collective bargaining ${ }^{57}$, the right for a strike ${ }^{58}$, to access information concerning risks the employee is exposed $\mathrm{to}^{59}$ or the right to be reinstated in case of unfair dismissal ${ }^{60}$, right for the strike of solidarity ${ }^{61}$.

The general basis for the ability to refer to other international instruments in its deliberations was acknowledged in Cudak v. Lithuania: "The Convention,

53 ECtHR, Oleksandr Volkov v. Ukraine (21722/11) 9.01.2013; Kamenos v. Cyprus (147/07) 31.10.2017; Sturua v. Georgia (45729/05) 28.03.2017; Xhoxhaj v. Albania (15227/19) 09.02.2020; Melike v. Turkey (35786/19) 15.06.2021; Miroslava Todorova v. Bulgaria (40072/13) 19/10/2021.

54 ECtHR, Halford v. the United Kingdom, (20605/92) 25.06.1997; Peev v. Bulgaria (64209/01) 26.07.2007; Köpke v. Germany (420/07) 05/10/2010.

55 ECtHR, Vines and others v. Norway (52806/09 22703/10) 05.12.2013; Brincat and others v. Malta (60908/11, 62110/11, 62129/11, 62312/11, 62338/11) 24.07.2014.

56 Sorensen, M., Do the rights and freedoms outlined in the ECHR in 1950 have the same significance in 1975?, in Fourth ECHR Colloquy, Rome, 1975, pp. 86-106.

57 ECtHR, Demir and Baykara v. Turkey (34503/97) Grand chamber, 12.11.2008.

58 ECtHR, ENERJI Yapi-Yol Sen c. Turquie (68959/01), 21.04.2009.

59 ECtHR, Brincat and others v. Malta (60908/11, 62110/11, 62129/11, 62312/11, 62338/11) 24.07.2014.

60 ECtHR, Oleksandr Volkov v. Ukraine (21722/11) 09.01.2013.

${ }_{61}$ ECtHR, the National union of rail, maritime and transport workers v. The United Kingdom (31045/10) 08.04.2014, para. 86. 
including Article 6, cannot be interpreted in a vacuum. The Court must therefore be mindful of the Convention's special character as a human rights treaty, and it must also take the relevant rules of international law into account". ${ }^{62}$ The Vienna Convention on the Law of Treaties (VCoLT) fixed the possibility to refer to "other relevant rules of international law" for the interpretation of international treaties (Article $31.3(\mathrm{C})$ ). The direct reference to this discretion can be found in numerous labour law cases. ${ }^{63}$ An analysis of the ECtHR's jurisprudence shows that the ECtHR resorted to Article 31.3 of the VCoLT as a means to support either an expansive or a restrictive reading of the ECHR when substantive issues of fundamental importance for the protection of human rights have presented themselves. ${ }^{64}$

Magdalena Forowicz, the author of profound research on the consideration of international law by the ECtHR, noted that the ECtHR finds itself at the apex of two diametrically different judicial paradigms; an open paradigm characterised by a high level of judicial activism and unhindered references to international law; and the closed paradigm, marked by judicial restraint and few references to international law. ${ }^{65}$

The so-called 'open paradigm' might be very often found in labour-related cases, particularly those related to Articles 4 (forced labour) and 11 (freedom of association). In these cases, the ECtHR always refers to the ILO Conventions and, more rarely, to the conclusions of the ILO bodies. Scholars noted that these references enable the ECtHR to fill certain gaps in the text of the ECHR. ${ }^{66}$ Indeed, key notions of those articles are not defined in the text of the ECHR - forced labour and the freedom of association. Therefore, the ECtHR defines these notions and the content of the freedom of association through the references to the ILO standards.

62 ECtHR, Cudak v. Lithuania (no. 15869/02), 23.03.2010 (par. 56)

63 ECtHR, R.M.T. v. The UK (31045/10) 08.04.2014, para. 76; Demir and Baikara v. Turkey, para. 65, Cudak v. Lithuania, para. 56.

64 Forowicz, M., The Reception of International Law in the European Court of Human Rights, Oxford University Press, 2010, p. 59.

65 Ibid., p. 4.

66 See more on earlier references of the ECtHR to the ILO and ESC standards in Merrills, J., The Development of International Law by the European Court of Human Rights, Manchester University Press, 1988, pp. 202-203. 


\subsection{Forced labour}

Forced labour, prohibited under Article 4 of the ECHR, is defined by the ECtHR in the light of the ILO Convention No. 29 concerning forced or compulsory labour. ${ }^{67}$ ILO Convention No. 29 on Forced or Compulsory Labour has been cited in all the cases considered to date under Article 4-2 of the ECHR. According to this instrument, the term forced or compulsory labour means all work or service which is exacted from any person under the menace of any penalty and for which the said person has not offered himself voluntarily. ILO Convention No. 29 lists the types of work that are excluded from the term 'forced and compulsory labour'. This list provided in Article 4-3 of the ECHR is largely analogous. However, in contrast with the ILO instrument, the ECHR lacks the precision of the meaning of 'emergency' used in this article.

In the case of Chitos v. Greece ${ }^{68}$ the ECtHR used the reference to the ILO Convention No. 29 to justify its reading of the provision of Article 4-3(b) as covering only compulsory military service. This article lists those types of activities that cannot be considered forced labour. The applicant, an army officer, argued that the obligation to pay a fee to the State to resign before the end of his period of service constituted forced labour. Therefore, this case was a significant opportunity for the ECtHR to delimit specifically the exceptions covered by Article 4-3(b). The ECtHR referred to the European Social Charter, the ILO Convention No. 29 and Recommendation CM/Rec (2010) 4 of the Committee of Ministers to the Member States on human rights of members of the armed forces.

\subsection{Freedom of association}

The lack of definition of the right to the freedom of association makes the ECtHR refer to the relevant provisions of the ILO Conventions, the ESC and the opinions of ILO bodies and the European Committee on Social Rights. ${ }^{69}$ The

67 ECtHR, Van Der Mussele v. Belgium (8919/80) 23.11.1983; Siliadin v. France (73316/01) 26.07.2005; Stummer v. Austria (37452/02) 07.07.2011; Graziani-Weiss v. Austria (31950/06) 18.10.2011.

68 ECtHR, Chitos v. Greece (51637/12) 04.06.2015.

69 ECtHR, Trade Union of the Police in the Slovak Republic and Others v. Slovakia (11828/08) 25.09.2012, para. 53; Vörđur Ólafsson v. Iceland (20161/06) 27.04.2010, para. 38; Associated Society of Locomotive Engineers and Firemen (ASLEF) v. The United Kingdom (11002/05) 27.02.2007, para. 67; Veniamin Tymoshenko and others v. Ukraine (48408/12) 02.10.2014. 
analysis of these sources, for instance, made the ECtHR conclude the existence of "core" 70 and "additional" collective rights. ${ }^{71}$ These international sources aid the ECtHR to determine the possible restriction of the freedom of association, set out in part 2 of Article 11. For example, in the case Tymoshenko and others v. Ukraine ${ }^{72}$, the ECtHR had to ascertain whether the "interests of national security or public safety or the protection of health or morals or the rights and freedoms of others" might justify the prohibition of strikes by pilots of a private company. The ECtHR used references to the provisions of ILO Conventions and the European Social Charter to show that the derogative clause must be read in a restrictive way. ${ }^{73}$

The most vivid application of the "open paradigm" is represented by the Demir and Baikara case. ${ }^{74}$ This position is largely consonant with the reasoning of the IACHR, when it based its conclusions on the norms of the ILO Convention not ratified by the respondent state. Here the Court referred to the norms of the European Social Charter which was not ratified by Turkey.

Considering the question about the right to collective bargaining of the municipal servants under Article 11 of the ECHR, the Court referred to the provisions of the ILO Conventions Nos. 87 and 98, No. 151. It also referred to the opinion of the CEACR to underline that only those officials who are directly employed in the administration of the State are excluded from the scope of Convention No. 98 (paras. 43-44). CEACR acknowledged that the only admissible exception to the right to organize might be in respect of the armed forces and the police. The reference to the CEACR's concluding observation was used by the ECtHR to demonstrate that ILO has already evaluated the situation in Turkey and, taking into account that it was cited in the final part of the judgement, that the Court rather agrees with this position (paras. 101-102).

The right to strike is another sphere where the ECtHR always refers to the ILO. This right is not mentioned in the text of the Article 11 and was deduced by the Court from "the right to form and to join trade unions for the protection of his interests". Interestingly, in the first cases concerning the right to strike, the

70 The right for collective bargaining, the negative freedom of association, see Demir and Baikara, Sorensen and Rasmussen v. Denmark [GC] (52562/99 52620/99) 11.01.2006.

71 For example, the right for the solidarity strike, see ECtHR, R.M.T. v. the UK (31045/10) 08.04.2014.

72 ECtHR, Veniamin Tymoshenko and Others v. Ukraine (48408/12) 02.10.2014.

73 Ibid., paras. 32-49.

74 ECtHR, Demir and Baykara v. Turkey (34503/97) Grand chamber, 12.11.2008. 
Court refrained from citing or referring to the ILO legal positions. No mention might be found in Schmidt and Dahlström v. Sweden, where it was stated that Article 11 leaves each State a free choice of the means to be used for the protection of trade unions' rights, "the grant of a right to strike represents without any doubt one of the most important of these means, but there are others". ${ }^{75}$ Despite the fact that the right to strike by 1976 was already recognized by the ILO bodies. For example, in the Resolution of the International Labour Conference concerning the Abolition of Anti-Trade Union Legislation in the States Members of the International Labour Organisation, adopted in 1957. It called for the adoption of "laws ... ensuring the effective and unrestricted exercise of trade union rights, including the right to strike, by the workers". ${ }^{76}$ In 1976, the ECtHR found the application concerning the right to strike inadmissible.

Ed Bates, the author of a very interesting research of the history of the ECtHR, argues that the Court "matured" with the years and became much bolder in the interpretation since the 1990s. ${ }^{77}$ This trend might be traced in the case law on strikes. Almost thirty years after the Schmidt and Dahlström decision, where no reference to the ILO might be found, the Court again had to consider the restrictions of the right to strike. In Enerji Yapi-Yol Sen v. Turkey, it stated that the strike was an important aspect for union members in protecting their interests, that it was recognized by the supervisory bodies of the ILO as "the inseparable corollary of the right to organize" and is protected by the ILO Convention No. 87 on freedom of association and protection of the right to organize. ${ }^{78}$ In 2009 , it found that banning a one-day public sector workers' strike violated Article 11 .

After five years, in 2014, the Court considered the famous case National Union of Rail, Maritime and Transport Workers v. the United Kingdom ${ }^{79}$, where the argument of the applicant union that the ban of the secondary strikes violated the freedom of association provided in Article 11 of the ECHR, was substantiated mostly by the references to ILO Conventions, and the interpretation given to them by the ILO bodies (paras. 27-33). The Court throughout the judgement

75 ECtHR, Schmidt and Dahlström v. Sweden (5589/72) 06.02.1976.

76 Gernigon, B.; Odero, A.; Guido, H., ILO principles concerning the right to strike, International Labour Review, vol. 137, no. 4, 1998, https:/www.ilo.org/wcmsp5/groups/ public/---ed_norm/---normes/documents/publication/wcms_087987.pdf.

77 Bates, E., The Evolution of the European Convention on Human Rights: From Its Inception to the Creation of a Permanent Court of Human Rights, Oxford University Press, 2010, p. 435.

78 ECtHR, Enerji Yapi-Yol Sen v. Turkey (68959/01) 21.04.2009.

79 ECtHR, The R.M.T. v. United Kingdom (31045/10) 08.04.2014. 
considered the positions of the ILO on this point, establishing that the secondary action was recognised and protected as part of trade-union freedom under ILO Convention No. 87. Further, it stressed though that its jurisdiction was limited to the ECHR and that it had no competence to assess the respondent State's compliance with the relevant standards of the ILO containing a "more specific and exacting norm regarding industrial action." ${ }^{\prime 80}$ The latter stance of the Court seems to be a caution against too much reliance on the ILO standards. The Court might refer to ILO positions but they do not form obligatory lines of reasoning, rather a kind of the practical framework for the reflection.

In a more recent case on a right to strike - Ognevenko v. Russia - the Court extensively cited the ILO positions on the limits to the right to strike. The case was about the dismissal of a train driver for taking part in a strike. The strike for railway staff is prohibited by the Federal Law of 10 January 2003 no. 17FZ "On Railway Transport in Russia". The Court considered the opinions of the CFA and the CEACR ${ }^{81}$, who were unanimous in the definition of essential services and in urging Russia to amend the legislation prohibiting strikes for railway staff. ${ }^{82}$

Provided a very developed jurisprudence of the CFA on the point of essential services and the restrictions of the rights to strike, avoiding this source in the judgment by the ECtHR might lead to the lack of legitimacy as the ECHR itself says nothing about the strike. Even though CFA positions are not mentioned in the Vienna Conventions, relying on them is a win-win method, ensuring support of the judgment from the part of the experts and a harmonious reading of the norm in line with other international instruments. Such a reading is particularly needed in relation to the right to strike when this right ${ }^{83}$ is contested by the employer's representatives at the ILO. ${ }^{84}$

It should be particularly emphasized that the reference of the ECtHR to the positions of the ILO bodies on the right to strike and the explicit recognition

80 ECtHR, The National Union of Rail, Maritime and Transport Workers v. the UK (31045/10) 08.04.2014, para. 106.

81 ECtHR, Ognevenko v. Russia 20.11.2018, Application no. 44873/09, paras. 20-23, 26.

82 See note above.

83 ECtHR, Enerji Yapi-Yol Sen c. Turquie (N 68959/01) 21.04.2009.

84 Gerasimova E.; Kolganova S., The Right for Strike in ILO Jurisprudence: Crisis of Recognition?, Law Journal of the Higher School of Economics, no. 4, 2016, pp. 184-197; Swepston, L., Crisis in the ILO Supervisory System: Dispute over the Right to Strike, International Journal of Comparative Labour Law and Industrial Relations, no. 2, 2013, pp. 199-218. 
of this right as a part of the freedom of association is very important in the situation when the employers' representatives at the ILO deny the fact that strikes are regulated by ILO Conventions. ${ }^{85}$

Ognevenko is another case contribution of the ECtHR to the support of the right to strike on the international level. It is the first binding judgment of the human rights body, which indirectly acknowledges that the general prohibition of strikes for the railway staff is incompatible with the human rights standards, namely with Article 11 of the ECHR. It is an example of the interconnection between human rights instruments (ECHR) and the ILO standards. It demonstrates that the human rights bodies seek to develop a common understanding of human rights not only among UN agencies ${ }^{86}$ but also a kind of global common understanding between the UN and regional human rights bodies.

\section{CONCLUSIONS}

Examples of the influence of ILO standards on the protection of labour rights by the CESCR and the ECtHR demonstrate that the reference to the ILO Conventions is a way to ensure the evolution of labour rights protection. It permits a more harmonious interpretation of labour rights at different levels of human rights adjudication (international, regional) and makes the regulation of these rights more coherent and systematic.

The interpretations of the ILO norms by the CEACR and the CFA are always referred to in the human rights jurisprudence when the cases relate to the freedom of association. Such references legitimize the legal reasoning, making it more solid and provide arguments for widening the scope of the human rights instruments. The ILO standards fill the gaps in the ICESCR and the ECHR providing concepts, standards for the regulation of the different aspects of the working conditions. It is also a method of adjusting the interpretation of the human rights instruments to the present-day conditions. It should also be pointed out that the reference to the ILO standards contributes to the universal understanding of labour rights as human rights.

85 Hornung-Draus, R., The right to strike in the ILO system of standards: Facts and fiction, Comparative Labor Law and Policy Journal, vol. 39, no. 3, 2018, pp. 531-536.

86 See UN Statement of Common Understanding on Human Rights-Based Approaches to Development Cooperation and Programming, 2003. 


\section{BIBLIOGRAPHY}

Albin, E.; Mantouvalou V., The ILO convention on domestic workers: From the shadows to the light, Industrial law journal, vol. 41, no. 1, 2012, pp. 67-78.

Brudney, J., The internationalization of sources of labour law, University of Pennsylvania Journal of International Law, vol. 39, 2017, pp. 1-71.

Carpenter, K., The International Covenant on Civil and Political Rights: A Toothless Tiger, North Carolina Journal of International Law, vol. 26, 2000, pp. 1-55.

Cassin, R., L'homme, sujet de droit international, et la protection des droits de l'homme dans la société universelle, in Rousseau C. (ed.), La technique et les principes du droit public. Etude en l'honneur de Georges Scelle, vol. 1, Librairie générale de droit et de jurisprudence, 1950, pp. 67-91.

Chacón, C., A Worker's Victory: Right to Strike Protected by Article 26 of the American Convention, International Labor Rights Case Law, vol. 6, no. 3, 2020, pp. 235-240.

Curtis, K., 100 years of the ILO in action: Reflections on inclusive collective representation and the organization's quest for social justice, King's Law Journal, vol. 32, no. 2, 2021, pp. 183-196

De Beco, G., The Indivisibility of Human Rights and the Convention on the Rights of Persons with Disabilities, International \& Comparative Law Quarterly, vol. 68, no. 1, 2019, pp. 141-160.

Dupré, C., The Age of Dignity: Human Rights and Constitutionalism in Europe, Bloomsbury Publishing, 2016.

Ebert, F.; Oelz, V., Bridging the gap between labour rights and human rights: The role of ILO law in regional human rights courts, ILO, 2012.

Eide, A., Realization of Social and Economic Rights and the Minimum Threshold Approach, Human Rights Law Journal, vol. 10, no. 1-2, 1989, pp. 35-51.

Fenwick, C., The International Labour Organisation: An Integrated Approach to Economic and Social Rights, in Langford, M. (ed.), Social Rights Jurisprudence: Emerging Trends in International and Comparative Law, Cambridge University Press, 2008, pp. 591-612.

Forowicz, M., The Reception of International Law in the European Court of Human Rights, Oxford University Press, 2010.

Gerasimova, E.; Kolganova S., The Right for Strike in ILO Jurisprudence: Crisis of Recognition?, Law Journal of the Higher School of Economics, no. 4, 2016, pp. 184-197.

Gormley, P., The Emerging Protection of Human Rights by the International Labour Organization, Albany Law Review, vol. 30, 1966, pp. 13-51. 
Hornung-Draus, R., The right to strike in the ILO system of standards: Facts and fiction, Comparative Labor Law \& Policy Journal, vol. 39, no. 3, 2018, pp. 531-536. Jenks, C. W., Human rights and international labour standards, Stevens, 1960.

Jenks, C., Human Rights, Social Justice and Peace: The Broader Significance of the ILO Experience, in Eide, A.; Schou, A. (eds.), International Protection of Human Rights: Proceedings of the Seventh Nobel Symposium, Oslo, September 25-27, 1967, Almqvist and Wiksell, 1968, pp. 227-260.

Kaufmann, J., Conference Diplomacy: An Introductory Analysis, Palgrave Macmillan, 2016

Kellerson, H., The ILO Declaration of 1998 on fundamental principles and rights: A challenge for the future, International Labour Review, no. 137, 1998, pp. 223-228.

Klabbers, J., Marginalised International Organizations: Three Hypotheses Concerning the ILO, in Blanpain, R.; Liukkunen, U.; Yifeng, C. (eds.), China and ILO Fundamental Principles and Rights at Work, Kluwer, 2014, pp. 181-196.

Koliev, F.; Lebovic J., Selecting for Shame: The Monitoring of Workers' Rights by the International Labour Organization, 1989 to 2011, International Studies Quarterly, vol. 62, no. 2, 2018, pp. 437-452.

Kunnemann, R., A coherent approach to human rights, Human Rights Quarterly, vol. 17, 1995, pp. 323-342.

Langford, M.; King, J., Committee on Economic, Social and Cultural Rights. Past, Present and Future, in Langford, M. (ed.), Social Rights Jurisprudence: Emerging Trends in International and Comparative Law, Cambridge University Press, 2008, pp. 477-516.

Lyutov, N., Norms of jus cogens and international labor law, Lex Russica, no. 12, 2014, pp. 1547-1556.

Lyutov, N., The ILO System of International Labour Standards and Monitoring Procedures: Too Complicated to Be Effective, Zbornik Pravnog Fakulteta u Zagrebu, vol. 64, no. 2, 2014, pp. 255-276.

Madariaga Cuneo, I., ILO Convention 169 in the inter-American human rights system: consultation and consent, The International Journal of Human Rights, vol. 24, no. 2-3, 2020, pp. 257-264.

Mantouvalou, V., Labour Rights in the European Convention on Human Rights: An Intellectual Justification for an Integrated Approach to Interpretation, Human Rights Law Review, vol. 13, no. 3, 2013, pp. 529-555.

Merrills, J., The Development of International Law by the European Court of Human Rights, Manchester University Press, 1988. 
Monaghan, K., The Committee of Experts on the Application of Conventions and Recommendations: The Centenary Year, King's Law Journal, vol. 32, no. 2, 2021, pp. 197-206.

Robertson, R., Measuring State Compliance with the Obligation to Devote the 'Maximum Available Resources' to Realizing Economic, Social, and Cultural Rights, Human Rights Quarterly, vol. 16, no. 4, 1994, pp. 693-714.

Sepúlveda, M., The nature of the obligations under the International Covenant on Economic, Social and Cultural Rights, Intersentia nv, 2003.

Skogly, S., Beyond national borders: States' human rights obligations in international cooperation, Intersentia nv, 2006.

Skogly, S., The Requirement of Using the 'Maximum of Available Resources' for Human Rights Realisation: A Question of Quality as Well as Quantity?, Human Rights Law Review, vol. 12, no. 3, 2012, pp. 393-420.

Sorensen, M., Do the rights and freedoms outlined in the ECHR in 1950 have the same significance in 1975?, in Fourth ECHR Colloquy, Rome, 1975, pp. 86-106.

Ssenyonjo, M., Reflections on state obligations with respect to economic, social and cultural rights in international human rights law, The International Journal of Human Rights, vol. 15, no. 6, 2011, pp. 969-1012.

Standing, G., The ILO: An agency for globalization?, Development and Change, vol. 39, 2008, pp. 355-384.

Swepston, L., Crisis in the ILO Supervisory System: Dispute over the Right to Strike, International Journal of Comparative Labour Law and Industrial Relations, no. 2, 2013, pp. 199-218.

Valticos, N., International Labour Standards and Human Rights: Approaching the Year 2000, International Labour Review, vol. 137, no. 2, 1998, pp. 135-147. 


\section{Sažetak}

\section{Elena Sychenko*}

\section{DOPRINOSI MOR-a JURISPRUDENCIJI MEĐUNARODNIH TIJELA ZA LJUDSKA PRAVA}

U radu se obrađuje uloga Međunarodne organizacije rada (MOR) prilikom razmatranja slučajeva i pri tumačenju međunarodnih instrumenata za zaštitu ljudskih prava od strane Odbora za ekonomska, socijalna i kulturna prava te Europskog suda za ljudska prava. Sobzirom na to da radnička prava čine dio međunarodno priznatih ljudskih prava, autorica istražuje u kojoj su mjeri standardi i argumentacija MOR-a prihvaćeni u sudskoj praksi i pri tumačenju međunarodnih instrumenata za zaštitu ljudskih prava od strane drugih medunarodnih tijela. Analiza jurisprudencije Odbora za ekonomska, socijalna i kulturna prava te Europskog suda za ljudska prava pokazuje da se u slučajevima koji se odnose na radnička prava uvijek referira na standarde i argumentaciju MOR-a, pri čemu oni služe i kao izvor "supstancijalnog nadopunjavanja" i Međunarodnog pakta o gospodarskim, socijalnim i kulturnim pravima i Europske konvencije o ljudskim pravima.

Ključne riječi: radnička prava, ljudska prava, Europski sud za ljudska prava, Međunarodna organizacija rada, Odbor za ekonomska, socijalna i kulturna prava

Dr. sc. Elena Sychenko, izvanredna profesorica Pravnog fakulteta Državnog sveučilišta u Sankt Petersburgu, ul. K. Marksa, d. 36a, kv. 21, Gatchina, Leningrad region, Russia; e.sychenko@mail.ru;

ORCID ID: orcid.org/0000-0002-7045-9218 